\title{
Typological diversity and ecological features of the middle taiga forests of Central Siberia
}

\author{
Leonid Krivobokov ${ }^{1 *}$, Andrej Zverev ${ }^{2}$, Liudmila Mukhortova ${ }^{1}$, Oksana Sergeeva ${ }^{1}$, and \\ Sergej Rosbakh ${ }^{3}$ \\ ${ }^{1}$ Sukachev Institute of Forest SB RAS, 50/28 Akademgorodok, Krasnoyarsk, 660036, Russia \\ ${ }^{2}$ Tomsk State University, 36 Lenin st., Tomsk, Russia, 634050 \\ ${ }^{3}$ University of Regensburg, 31 Universität str., Regensburg, Germany, D-93040
}

\begin{abstract}
The main types of forest plant communities in the southern part of the Central Siberian Plateau (the lower reaches of the Podkamennaya Tunguska River Basin) were separated. Basic ecological gradients crucial for formation and functioning of these types of plant communities were identified using the methods of ordination.
\end{abstract}

\section{Introduction}

Inventory of alpha and beta diversity, identification of ecological peculiarities and geographical regularities of contemporary vegetation functioning are crucial for zonation and mapping of large areas. Furthermore, it plays an important role in studying the dynamics of ecosystems, developing strategies and specific approaches for rational nature management and nature conservation. Particularly, this is relevant for poorly investigated territories of the northern part of Siberia. The aim of the study is to identify the typological diversity and ecological regularities of forest vegetation of South Evenkia in the basin of the lower reaches of the Podkamennaya Tunguska River. Specifically, we made an ecological-phytocenotic classification of forest vegetation of this region followed by an ordination of forest plant communities to detect the environmental factors driving their structure and composition.

\section{Materials and methods}

The study area is located in the southern part of the Central Siberian Plateau $\left(61^{\circ} \mathrm{N}, 96^{\circ} \mathrm{E}\right)$. The area has a mid-mountain relief, with elevations ranging from 150 to $700 \mathrm{~m}$ above sea level (a.s.l.).Traps (cank) are the main bed rocks; along the valleys of large rivers there are outcrops of carbonate marine Cambrian deposits [1]. The study area is located within the boundaries of the discontinuous permafrost zone. The climate is continental, moderately humid; the sum of air temperatures for a period with a temperature above $10^{\circ} \mathrm{C}$ is $1200{ }^{\circ} \mathrm{C}$. The average annual air temperature is $-6.3^{\circ} \mathrm{C}$, the average January temperature is $-29.6{ }^{\circ} \mathrm{C}$,

\footnotetext{
* Corresponding author: leo kr@mail.ru
} 
the average July temperature is $16.9^{\circ} \mathrm{C}$. The average annual rainfall is about $400-500 \mathrm{~mm}$ [2].

According to forest vegetation zonation [3], the research area is located within the Middle Siberian plateau forest region. The research area is at the junction of the Yenisei and Angara-Tunguska forest provinces, and within the latter it is included into the Podkamenno-Tunguska district of medium-taiga larch-coniferous forests. The classification of forest vegetation of the region was carried out using the ecological-phytocoenotic approach [4]. To identify forest types, 67 complete geobotanical relevés (temporary plots) were used. The cover of species was recorded in the Braun-Blanquet scale [5].

The phytoindication processing of relevés by the method of weighted averaging with account taken of the amplitudes of tolerance of indicator taxa for environmental ordination was carried out in IBIS 7.2 [6]. Phytoindication systems by I.A. Tsatsenkin et al. ([7]; the average proportion of indicator taxa in the complete species lists for soil moisture and nutrient factors is $93.471 \pm 0.426 \%$ ) and by D.N. Tsyganov ([8]; the average proportion for temperature factor is $79.770 \pm 0.991 \%$ and for the acidity factor is $41.016 \pm 0.905 \%$ ) were used. Detrended Correspondence Analysis (DCA) was performed in PAST 3.26 [9]. Species names follow the regional check-lists [10-12].

\section{Results and discussion}

In the study area, five types of forest vegetation were detected:

Type 1: Larch bog blueberry-herb mixed-green-moss forests occupy low-sloped flat or convex slopes of light exposures in the altitude range of 180-310 m above s.l. Forests of this type grow on podbur soils that are formed mainly on carbonate rocks.

Type 2: Siberian pine-spruce bilberry-grass-green-moss forests occupy the tops of hills and the upper parts of the gentle slopes of all exposures at altitudes of 400-700 m above s.l. The most common soils for these forests are sod-podbur and lithozems soils.

Type 3: Spruce-birch horsetail-bluejoint-herb mixed forests are found on the concave parts of the slopes and in the valleys of rivers and streams, within the altitude of 170-600 m above s.l. Forests of this type grow on drained humus soils.

Type 4: Larch subshrubs-green-mosses forests prevail on river terraces and gentle shady slopes within 150-300 m above s.l. Phytocenoses of this type grow on peat soils, with permafrost at a depth of $40-50 \mathrm{~cm}$ of the mineral profile, and having a peat horizon of 20-30 cm thick.

Type 5: Larch leatherleaf-sphagnum forests are swampy sparse larch forests of stream valleys, floodplain river terraces, in the altitude range of 150-300 m above s.l. They usually found on flat places or low-sloped slopes, where drainage is difficult due to the close occurrence of permafrost and a well-developed peat layer. Waterlogged cryozems with a close occurrence $(15-20 \mathrm{~cm})$ of ice permafrost prevail in the soil cover of this forest type.

The DCA detected clear differences between the identified forest types on the 2 first virtual axes of the environmental gradients (Fig. 1).

The results of intermediated ecological ordination (Fig. 2) showed the regular differences between the identified forest types by the factors of soil moisture and fertility. The least moist soils are associated with Larch bog blueberry-herb mixed-green-moss forests (Type 1) light slopes, and the greatest over moistening are characterized by Larch leatherleaf-sphagnum forests (Type 5). Spruce-birch horsetail-bluejoint-herb mixed forests (Type 3), Siberian pine-spruce bilberry-grass-green-moss forests (Type 2) and Larch subshrubs-green-mosses forests (Type 4) showed equal positions in the degree of soil moisture, but these types differ in a consistent decrease in soil fertility in this series. 


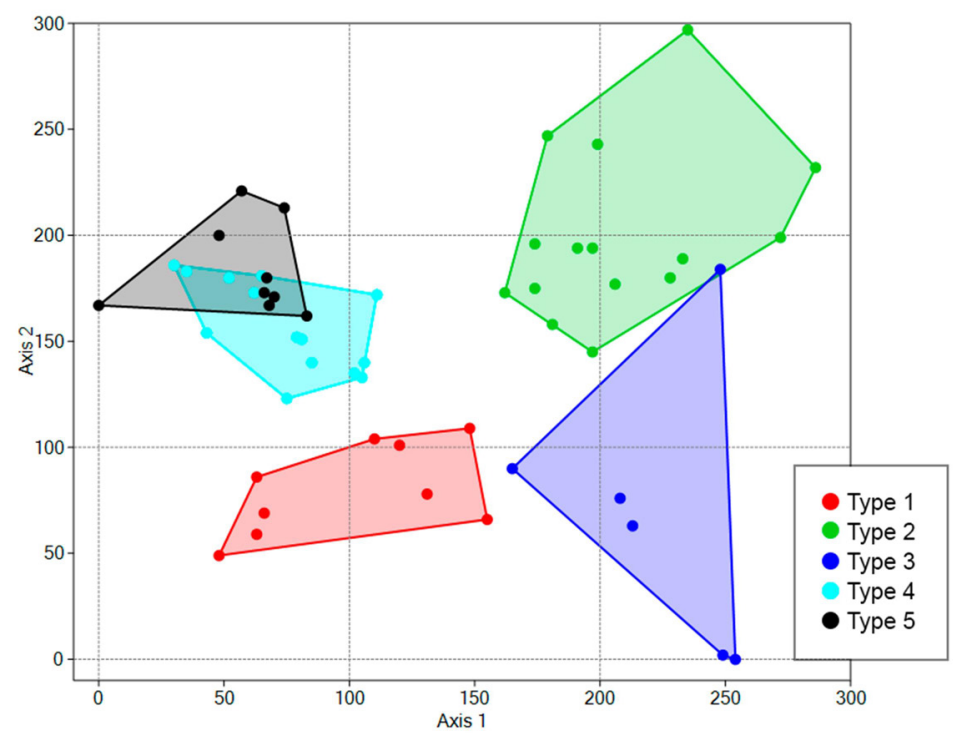

Fig. 1. DCA-ordination of forest plant communities (types) of the study region in the first two axes.

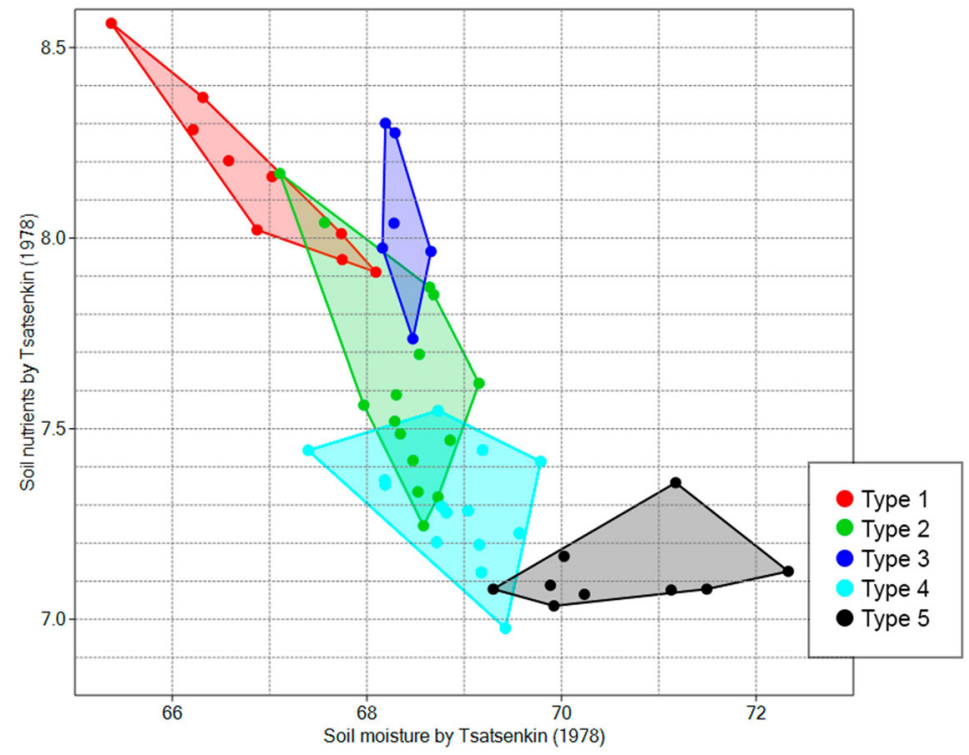

Fig. 2. Indirect ordination of forest plant communities (types) according to the conditions of soil fertility and moisture. 
Studied forest types also differed on the factors of temperature and soil acidity (Tsyganov, 1983) (Fig. 3). Temperature of forest types increases from Larch leatherleaf-sphagnum forests (Type 5) to shadow Larch subshrubs-green-mosses forests (Type 4). The most thermophilic forest types are Siberian pine-spruce bilberry-grass-green-moss forests (Type 2) on the tops of hills, Spruce-birch horsetail-bluejoint-herb mixed forests (Type 3) in the river valleys and Larch bog blueberry-herb mixed-green-moss forests (Type 1) on the light slopes. The latter two types are also characterized by less acidic soils (5.0-6.4 points of acidity) than the other groups (4.0-5.0 points of acidity).

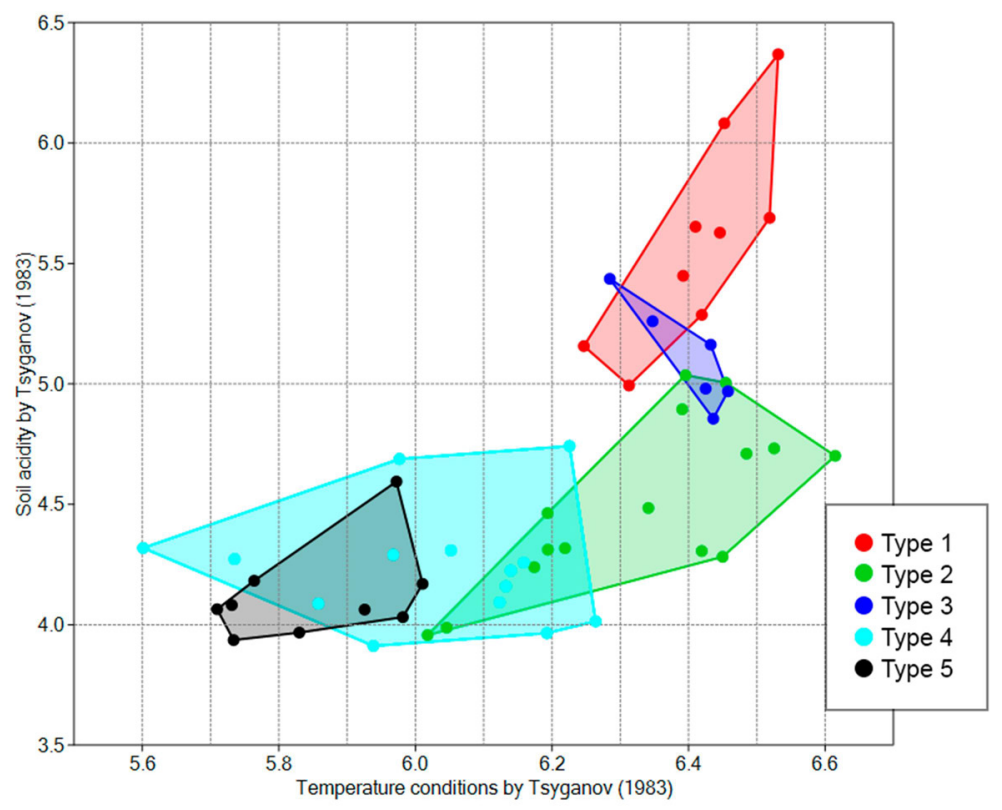

Fig. 3. Indirect ordination of forest plant communities (types) according to the conditions of soil acidity and heat supply of habitats.

\section{Conclusions}

The results of the ordination analysis indicated that the main factors providing the typological diversity of the study forest vegetation, which include light-coniferous, darkconiferous, and small-leaved types of phytocenoses, are complex mid-mountain relief, climatic conditions, and the composition of underlying strata, including both carbonate and trap rocks.

The research was carried out within the framework of the State Assignments of Sukachev Institute of Forest SB RAS "Biodiversity of primary coniferous and derived forest ecosystems" (state registration number: AAAA-A17-117101820003-0) and "The dynamics of the Siberian forests in a changing climate: monitoring the vital state, productivity and area of the main forest-forming species of woody plants "(state registration number: AAAA-A17-117101940016-3), as well as with partial financial support of Russian Foundation for Basic Research (grant No. 18-04-01068-a). 


\section{References}

1. Central Siberia, I. P. Gerasimova (Ed.) (Nauka, Moscow, 1964) (in Russian)

2. Climatic Atlas of the USSR F.F. Davitaja (Ed.) (V. 1, Moscow, 1960) (in Russian)

3. I. A. Korotkov, Forest growing zoning of Russia and the republics of the former USSR, in Carbon in the ecosystems of forests and swamps of Russia, V.A. Alekseev, R.A. Birdsey (Ed.) (Inst. For., Rus. Acad. Sci., Sib. Br., Krasnoyarsk, 29-47, 1994) (in Russian)

4. V. N. Sukachev, Selected Works, General principles and program for the study of forest types (V. 1, 259-310, Nauka, Leningrad, 1972) (in Russian)

5. V. Westhoff, E. van der Maarel, The Braun-Blanquet approach, in Classification of plant communities, R. H. Whittaker (Ed.), (Dr. W. Junk Publishers, The Hague, 289$399,1978)$

6. A. A. Zverev, Information technology in vegetation cover research (TML-Press, Tomsk, 2007) (in Russian)

7. Guidelines for the environmental assessment of the forage lands of the tundra and forest zones of Siberia and the Far East on vegetation cover (VIK, Moscow, 1978) (in Russian)

8. D. N. Tsyganov, Phytoindication of ecological regimes in the subzone of coniferousdeciduous forests (Nauka, Moscow, 1983) (in Russian)

9. Ø. Hammer, D. A. T. Harper, Paleontological Data Analysis (Blackwell, Malden, Oxford, Carlton, 2006)

10. S. K. Cherepanov, Vascular plants of Russia and neighboring states (within former USSR) (Mir i sem’ya, Saint-Petersburg, 1995) (in Russian)

11. M. S. Ignatov, O. M. Afonina, E. A. Ignatova, Arctoa, 15, 1-13 (2006)

12. A checklist of the lichen flora of Russia (Nauka, Saint-Petersburg, 2010) (in Russian) 